\title{
Primitive Neuro Ectodermal Tumor (PNET) in infant diagnosed by histopathology and immunohistochemistry techniques A Case Report
}

\author{
G. Alit Artha, Moestikaningsih, S. Herman, W. Winarti
}

\begin{abstract}
Abstrak
Kasus 'Primitive Neuro Ectodermal Tumor' (PNET) sangat jarang dan sangat sukar didiagnosis. Sebuah kasus PNET didiagnosis dengan teknik histopatologi dan pemeriksaan imunohistokimia. Seorang bayi laki-laki umur 4 bulan diperiksakan ke rumah sakit dengan benjolan pada dinding dada sejak bayi tersebut berumur 3 hari. Benjolan tersebut makin lama makin membesar hingga akhirnya mencapai diameter $\pm 10 \mathrm{~cm}$, selanjutnya penderita dibawa ke klinik. Benjolan tersebut terfiksir pada dinding dada dengan batas tidak tegas, pada kulit diatas tumor tampak dua ulkus. Selanjutnya tumor tersebut didiagnosis sebagai suatu hemangioma. Secara makroskopis tumor berukuran $17 \times 13 \times 5,5 \mathrm{~cm}$, berbatas tidak tegas, berwarna putih dan lunak. Secara mikroskopis massa tumor terdiri atas sel-sel berukuran kecil yang tidak berdiferensiasi, berbentuk bulat-oval, dengan inti hiperkromatik, dan sebagian membentuk struktur roset, Homer-Wright di antara bagian lainnya yang difus. Mitosis 7/10 HPF, nekrosis minimal kurang dari $25 \%$. Gambaran ini sesuai dengan suatu 'malignant small round sel tumor', Pada pemeriksaan imunohistokimia dengan panel antibodi meliputi Vimentin, NSE, Chromogranin dan CD99 menunjukkan Vimentin positif lemah-sedang, NSE negatif-positif lemah, Chromogranin negatif-positif lemah dan CD99 positif lemah-sedang. Secara keseluruhan, berdasarkan pemeriksaan makroskopis, histopatologik, dan imunohistokimia disimpulkan sebagai suatu 'Malignant Small Round Cell Tumor' yang sesuai dengan PNET / ES (Ewing's sarcoma) yang perlu di konfirmasi dengan pemeriksaan sitogenetik. (Med J Indones 2007; 16:108-12)
\end{abstract}

\begin{abstract}
Primitive Neuro Ectodermal Tumor (PNET) is rare and difficult to diagnose. A case of PNET was diagnosed based on histopathological and immunohistochemical findings. A 4-month-old infant was admitted to the hospital with a tumor on the midline of his chest wall since he was 3 days old. The tumor was fixed on the chest wall and had ill-defined margin, enlarged over time and reached more than $10 \mathrm{~cm}$ in diameter when he was brought to a clinician. Two small ulcers were seen on the skin overlying the tumor. It was diagnosed as soft tissue tumor suggestive of a hemangioma. The tumor was $17 \times 13 \times 5.5 \mathrm{~cm}$ in size, white colored and firm to the touch. Microscopic examination revealed malignant small round cells with round to ovoid nuclei, coarse chromatin and scanty cytoplasm. Most cells were arranged in a solid pattern with scattered Homer-Wright rosettes. The mitotic count was 7/10 HPF, and necrosis was minimal (less than 25\%). On immunohistochemical examination, the cells showed weak to moderate immunoreactivity to Vimentin and CD99, but showed negative to weak positive reactivity to NSE and Chromogranin. Based on the clinical features, gross findings, histopathologic and immunohistochemical examinations, the case was diagnosed as a malignant small round cell tumor consistent with PNET / ES (Ewing's Sarcoma). To confirm the diagnosis, cytogenetic examination is suggested. (Med J Indones 2007; 16:108-12)
\end{abstract}

Keywords: PNET, histopathology, immunohistochemistry

Primitive Neuro Ectodermal Tumor (PNET) and Ewing's Sarcoma (ES) are very rare neoplasms and very difficult to differentiate through conventional staining from other small cell neoplasms. These neoplasms are non-epithelial malignant neoplastic diseases which are grouped into one family and have

Department of Pathology, Faculty of Medicine Udayana University, Public General Hospital, Denpasar, Bali, Indonesia various morphologic pattern. ${ }^{1}$ The cells have small, uniformly rounded and pale nuclei, with finely granular chromatin and glycogen-rich cytoplasm. Usually they are arranged in an unspecific pattern. They may show larger cells with more irregular nuclei, and are arranged in Homer-Wright rosette or pseudorossette structure.

There are many other neoplastic diseases that have similar histomorphologic features, hence the diagnosis becomes difficult to make based on routine histo- 
pathological examination only (Hematoxyllin-Eosin staining). A panel of immunohistochemical staining may be needed to exclude differential diagnosis, but definitive diagnosis can only be made based on cytogenetic examination. ${ }^{1-6}$

This report of a PNET/ES case in a 4-month-old infant focuses on clinical features, gross examination, routine histomorphological and immunohistochemical examination.

\section{CASE}

A 4-month-old infant was admitted to the hospital with a complaint of having a tumor on his chest wall since he was 3 days old. The tumor was first noticed by his parents as a small nodule resembling a mosquito-bite, enlarged over time and reached about $10 \mathrm{~cm}$ in diameter. The tumor also showed two small ulcers on the overlying skin. Before the patient was referred to the Central Hospital in Denpasar, Bali, he was brought to the Public Health Center several times. Initially the doctor did not consider it as a neoplastic disease. Since the tumor was getting bigger, the doctor referred the patient to a regency hospital in Lombok, Nusa Tenggara Barat, before he was further referred to the Central Hospital Denpasar, Bali.

The patient was born through normal labor. During pregnancy, the mother has never taken any medication, including traditional ones. No history of similar disease or other cancers were noted in other family members.

The patient was admitted to the Central Hospital and was hospitalized there since September $9^{\text {th }}, 2005$ with a clinical diagnosis of soft tissue tumor, suspected as hemangioma. The tumor was located on the midline of the chest wall, immobile, with ill-defined margins, $15 \mathrm{~cm}$ in diameter, and painless. There were two small ulcers on the overlying skin. The patient's appearance and movement were normal. Vital signs and routine hematological findings were also within normal limit.

\section{Examination findings}

\section{Incisional biopsy}

On September $12^{\text {th }} 2005$ biopsy was carried out and the specimen was sent to the Pathology Department, Udayana University Medical Faculty.

\section{Gross appearance}

The specimen consisted of 4 small pieces of tissue, measuring $0.5 \times 0.2 \times 0.1 \mathrm{~cm}(1$ specimen) and $0.2 \times$ $0.1 \times 0.1 \mathrm{~cm}$ ( 3 specimens) in size, and white in color.

\section{Histological Findings}

On microscopic examination, the specimen mainly consisted of fibrous connective tissue. Several clusters of small neoplastic cells were seen invading the tissue. The cells had small,round to ovoid, and hyperchromatic nuclei. They were arranged in a diffuse pattern. The mitotic count was 6/10HPF, and necrosis was more than $50 \%$. Based on histomorphological examination, this biopsy specimen was diagnosed as malignant small round cell tumor, with several differential diagnosis: 1) Neuroblastoma, 2) Embryonal Rhabdomyosarcoma, 3) Ewing sarcoma/PNET and 4) Malignant Lymphoma. Immunohistochemical examination was suggested to get a definitive diagnosis.

\section{Post-operative Findings}

\section{Gross appearance}

Tumor excision was carried out on September $30^{\text {th }}$, 2005. On gross examination, the tumor was located in the subcutaneous tissue, $17 \times 13 \times 5.5 \mathrm{~cm}$ in size, white colored, with ill-defined margins, uncapsulated, with a few hemorrhagic foci. The margin of excision was $1 \mathrm{~cm}$ from the tumor mass.

\section{Histological Findings}

Microscopically, the tumor consisted of small undifferentiated cells with round to ovoid, hyperchromatic nuclei, some were arranged in Homer-Wright rosette, and some were diffuse. The mitotic count was $7 / 10$ HPF. Necrosis area was less then $25 \%$. This case was diagnosed as Malignant Small Round Cell tumor, suggestive of Neuroblastoma.

\section{Immunohistochemical Findings}

A specimen was sent to the Department of Anatomical Pathology, Faculty of Medicine, University of Indonesia in Jakarta for immunohistochemical examination. The immunostaining used Vimentine, NSE, Chromogranin and CD99. The result was negative to weak reactivity for NSE and chromogranin, but weak to-moderate positivity for vimentin and CD99.

Based on the clinical features, gross findings, histomorphological and immunohistochemical findings, this case was considered as Malignant Small Round Cell Tumor, consistent with Ewing's sarcoma/PNET. 

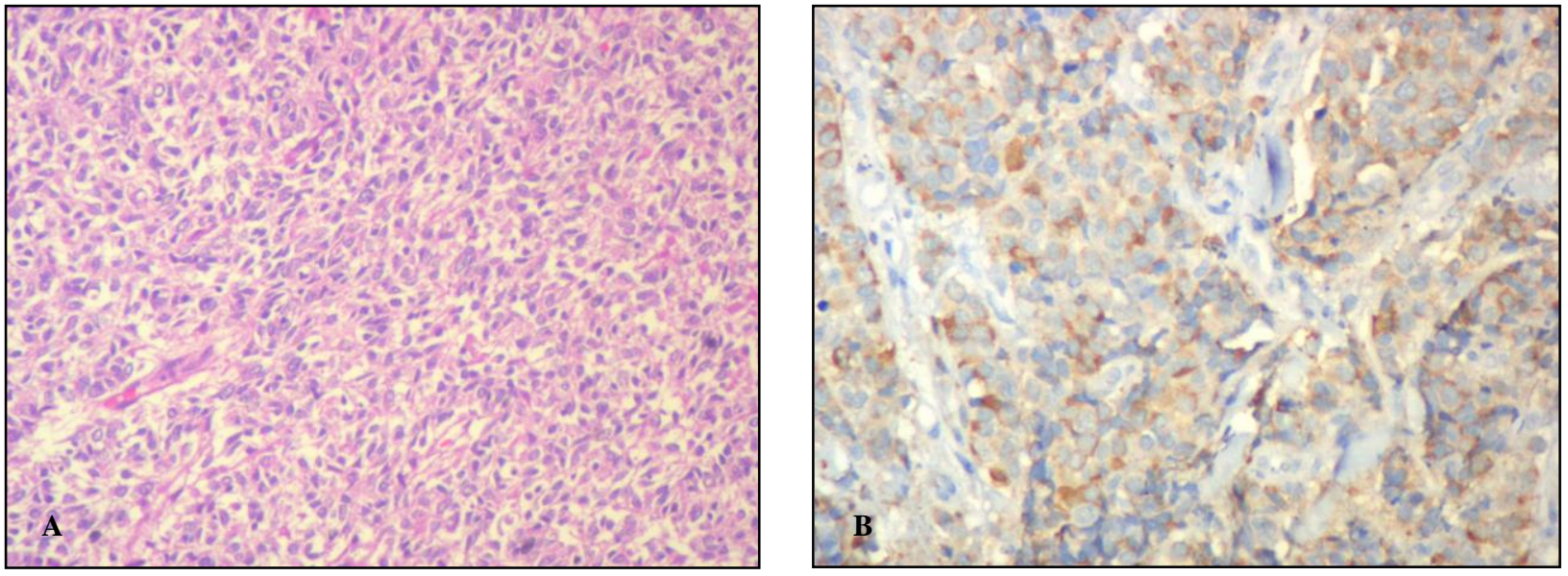

Figure 1. Small round cells arranged in solid pattern and Homer-Wright rosettes (1935P/2005, HE 20x and 40x)
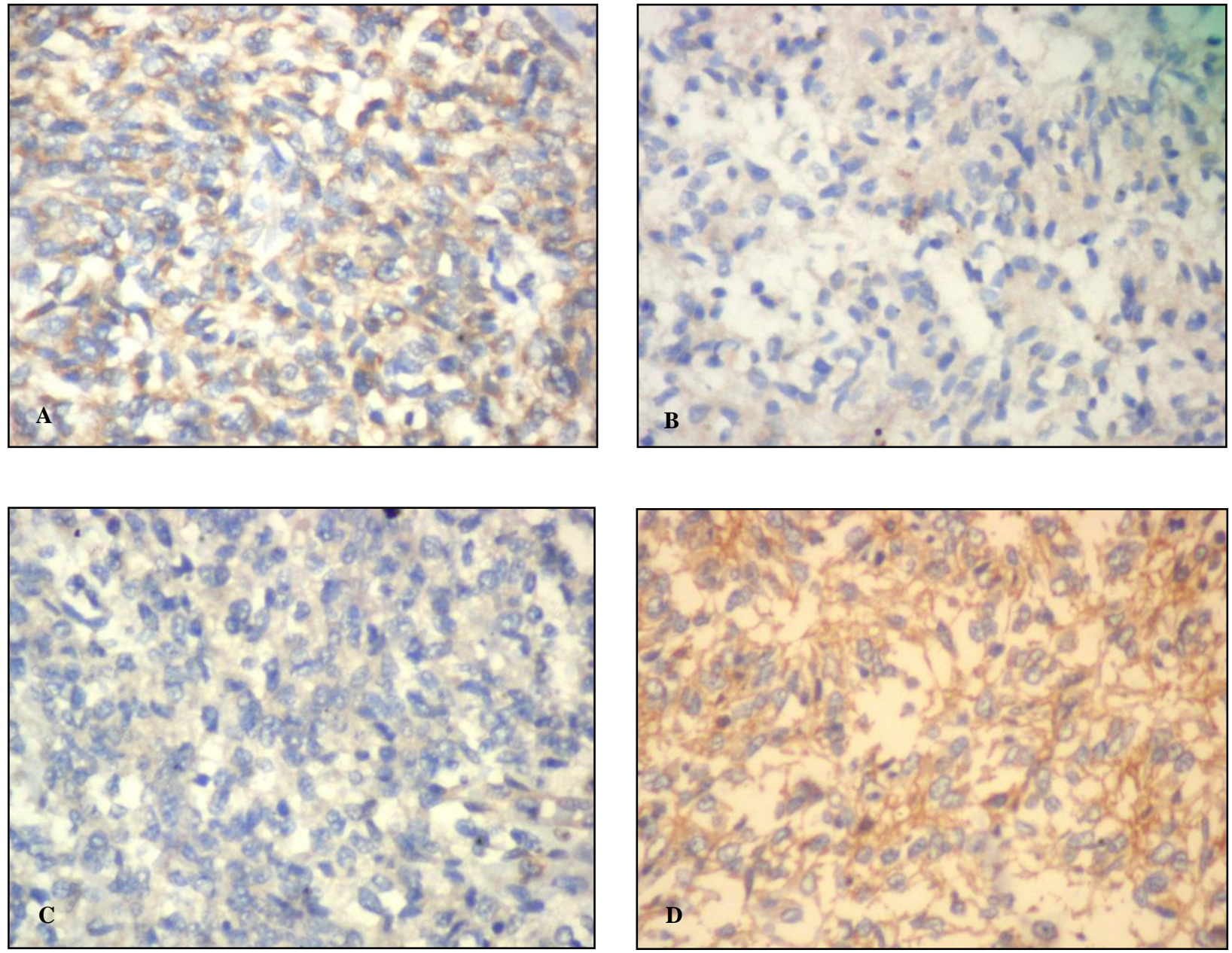

Figure 2. Tumor showed weak-moderate immunoreactivity for vimentin (A), negative-weak positive for chromogranin (B), negativeweak positive for NSE and weak-moderate positive for CD99(D). (1935PA/2005, 40x). 


\section{DISCUSSION}

Due to the similarity in histomorphology, immunohistochemical and cytogenetic examinations, at present it is believed that PNET and ES belonged to the same group of diseases. Males are affected more than females, mostly in the second and third decades of life. It is very rare in the age under 5 years and above 40 years. The main predilection sites are in the extremities and the chest, but may also affect bones, soft tissues or visceral organs. ${ }^{1,4}$ In this report, the patient was a boy, 4 months old, with a soft tissue tumor located on the chest wall.

The gross features of PNET/ES may vary greatly. The tumor may be lobulated or multi nodular, have welldefined border or ill defined margins, may be brown, yellow or grayish white in color. Commonly, the tumor is soft and friable, shows hemorrhagic, necrotic area, and may have cystic lesions. The mean diameter may reach $10 \mathrm{~cm}$, ranging from 2 to $40 \mathrm{~cm}$. In some cases may also attach to peripheral nerves. ${ }^{1,2,4}$ In this case the tumor has infiltrating margin, $17 \mathrm{~cm}$ in diameter, and white in color, friable and shows hemorrhagic area.

Because PNET/ES show a very wide range of morphology spectrum, diagnosis of PNET/ES is not easy to establish histomorpologically, even from specimens obtained through incision biopsy through open surgery. The specimen should represent every part of the tumor. In one case it may show one end of the spectrum, but in other cases it may show the other end of the spectrum, or in between features. The cells have uniform round to ovoid, nuclei with scanty to moderate amphophillic or eosinophillic cytoplasm, arranged in diffuse, lobulated, angiomatoid, alveolar or fascicular pattern. The nuclei often show irregular membrane, pale, finely granular chromatin with small round nucleoli. Most cells contain glycogen vacuole in their cytoplasms. Mitotic counts may vary from 5 to 50/10HPF. Sometimes, spindle or polygonal cells, metaplastic bone and cartilage tissue were found. The tumor shows delicate stroma. Lobules were separated by thin fibrovascular tissue. This kind of morphological finding previously was classified as ES. If the tumor cells were arranged in Homer-Wright rosette and pseudorosette, it is classified as PNET. The cells were small or moderate in size, round-ovoid, polygonal or spindle, and sometimes have abundant eosinophillic cytoplasm without vacuolization. These cells may show neural or rhabdoid appearance. Homer-Wright rosette was defined as cluster of eosinophillic fibrillary cytoplasm, surrounding by cells nuclei. If the central part of this structure contain blood vessel, it is called pseudorossete. One case may show transitional features. ${ }^{1-6}$

In our case, the specimen obtained from incisional biopsy was not representative, since it showed no predominant part of tumor mass. On microscopic examination, the biopsy specimen only showed foci of invasive undifferentiated cells with round to ovoid and hyperchromatic nuclei, arranged in diffuse pattern without any Homer-Wright rosette and pseudorossette formation. Hence, histomorphologically, the biopsy specimen can only be concluded as Malignant Small Round Cell Tumor, with many differential diagnosis, it may be neuroblastoma, Ewing's sarcoma/PNET, embryonal rhabdomyosarcoma, or malignant lymphoma.

Microscopic feature of the excisional specimen was very different. Almost all of the tumor mass consisted of small primitive cells with round to ovoid, hyperchromatic nuclei and showed Homer-Wright rosette formation, with very delicate stroma. Few necrosis foci were found. This kind of arrangement may be found in neuroblastoma and PNET/Ewing sarcoma. Therefore, embryonal rhabdomyosarcoma and malignant lymphoma can be excluded since rosette or pseudorossette structure was not a common feature of these neoplasms.

Immunohistochemical examination was carried out in order to get more definitive diagnosis of small round cell tumors. This technique used vimentin, LCA, NSE, Leu7, NF, and CD99. Vimentin is positive for all mesenchymal tumors, hence it is positive for neuroblastoma, Ewing sarcoma/PNET or embryonal rhabdomyosarcoma. While malignant lymphoma is negative since it arises from lymphoid tissue. Malignant lymphoma shows immunoreactivity for LCA (Leukocyte Common Antigen). ${ }^{3,6,7,8}$ In our case, the immunostaining shows positive staining for vimentin, there for malignant lymphoma can be excluded. Since the tumor which arises from or showed neuronal differentiation they may show positive immunostaining for neuroendocrine markers like Neuro-Specific Enolase (NSE), chromogranin and neuronal marker. For these examination, Embryonal Rhabdomyosarcoma may show negative result, whereas neuroblastoma and PNET/ES may show positive result. ${ }^{3,7}$ In our case, tumor showed immunoreactivity for NSE and chromogranin, therefore neuroblastoma or PNET/ES may be confirmed. Tumor was also positive for CD99, supporting PNET/ES. diagnosis. CD99 is recognized as a surface membrane protein called MIC2 which is located on the pseudo- 
autosomal region of chromosomes $\mathrm{X}$ and $\mathrm{Y}$. This immunostaining shows strong immunoreactivity in more than $90 \%$ of PNET cases and almost $100 \%$ of ES cases. ${ }^{1-4}$ In our case, the tumor showed weak tomoderate positivity to CD99 which may support the diagnosis of PNET/ES.

\section{REFERENCES}

1. Weiss SW, Goldblum JR, Primitive neuroectodermal tumors and related lesions. In: Weiss SW, Goldblum (eds). Enzinger and Weiss`s Soft Tissue Tumors, $4^{\text {th }}$ ed. St.Louis: Mosby; 2001. p.1265-321.

2. Scheithauer BW, Woodruff JM, Erlandson RA. Primary malignant tumors of peripheral nerve. In: Tumor of the peripheral nervous system. Maryland: Armed Force Institute of Pathology; 1999. 356-8.
3. Huves AG. Ewing's sarcoma. In: Bone Tumors, Diagnosis, Treatment and Prognosis, $2^{\text {nd }}$ ed. Philadelphia: WB Saunders Company; 1991. p.523-52.

4. Rorke LB, Hart MN, McLendon RE. Supratentorial primitive neuroectodermal tumours (PNET). In: Kleihues P, Cavenee WK (eds). Pathology and genetic, Tumor of the nervous system. Lyon: IARCPress; 2000. p.141-4.

5. Rosai J. Bone and joint. In: Rosai and Ackerman`s Surgical Pathology. $9^{\text {th }}$ ed. London: Mosby; 2004. p. 2172-8.

6. Sharma S, Mishra K, Agarwal S, Khanna G. Solid tumors of childhood. Indian J Pediatr. 2004; 71:501-4.

7. Muro-Cacho CA. The role of immunohistochemistry in the differential diagnosis of soft-tissue tumors. Cancer Control J. 1998; 5(1): 53-63.

8. Varmoor J, Baersch G, Decker S, Hotfilder M, Schafer KL, Pelken L, et al. Establishment of an In Vivo Model for Pediatric Ewing Tumors by Transplantation into NOD/Scid Mice. Pediatric Research. 2001:49:332-41. 